ROCZNIKI TEOLOGICZNE

Tom LXVIII, zeszyt 9 - 2021

DOI: https://doi.org/10.18290/rt.21689.8

STANISŁAW GRODŹ SVD

\title{
(SUSTAINABLE) DEVELOPMENT THROUGH DELIVERANCE (MINISTRY) IN WEST AFRICA?
}

\begin{abstract}
A b s t r a c t. One might wonder what both matters named in the title have in common because they belong to two rather different world perceptions. In the conclusion of his latest book (2015) Paul Gifford still insisted that development - conceived according to the Western secularised perception - was hardly possible there, where people continue operating within the "enchanted" worldview. It seems, however, that this "impossibility" may actually become possible, although through quite a surprising twist of mind called "decolonisation of development".
\end{abstract}

Key words: African Initiated Churches; Neopentecostalism; sustainable development; deliverance ministry.

A recent book on development and the African Initiated Churches (AICs) have sparked off this article. The editors and contributors argue for a new approach in researching the interface between development and religion. They also advocate perceiving the AICs as new partners in carrying out the development work in Africa. ${ }^{1}$ My geographical focus is placed on Ghana as the area known to me partly from the first-hand experience. I am presenting a broadly brushed picture of the interests and directions in which research of other scholars has been going on in recent years. The above-mentioned book confirms a tendency to combine things that several years ago seemed to some

Dr STANISŁAW Grodź SVD - Anthropos Institut, Arnold-Janssen-Str. 30, 53757 Sankt Augustin, Germany; e-mail: grodz@anthropos.eu

${ }^{1}$ Philipp Öhlmann, Wilhelm Gräb, and Marie Luise Frost (eds.), African Initiated Christianity and the Decolonisation of Development. Sustainable Development in Pentecostal and Independent Churches (Abingdon: Routledge, 2020). 
researchers entirely incompatible. For that reason, two words in the title have been placed in brackets.

As I remain on a rather general level of reflection in this article, I do not differentiate between various types of the so-called African Initiated Churches, treating them as a diversified but one category. The current "pentecostalisation" of many Christian groups and churches - the AICs in particular gives one reason to do so. Another one comes in line with the recent tendency followed by the editors of the above-mentioned book, i.e. to accept a selfdefinition. John N. Gichimu described an AIC in the following way:

a church that acknowledges Jesus Christ as Lord, and which has separated by seceding from a mission church or an existing African independent church, or has been founded as an independent entity under African initiative and leadership. ${ }^{2}$

That captures a longer description that can be found at the website of the Organization of African Instituted Churches (OAIC). ${ }^{3}$

\section{1. "MODERN" VS “ENCHANTED"}

In the 1990s, Paul Gifford was one of those researchers of Christianity in Africa who maintained that modernity encountered difficult inroads into the African context because the people there operated within a different worldview, which he called "enchanted". ${ }^{4} \mathrm{He}$ claimed that the Neopentecostal

\footnotetext{
2 John Njeru Gichimu, "History and Profile of OAIC," in Anthology of African Christianity, eds. Izabel Apawo Phiri et al. (Oxford: Regnum Books International, 2016), 810.

3 “AIC's are homegrown African churches, founded originally during the colonial period, that have developed indigenous forms of worship, theology and social organization, all deeply inspired by a vision that is both Christian and African. As followers of Jesus Christ, we are called to respond with conviction to the challenges, such as entrenched poverty, ill health and the breakdown of African cultural and social systems, that require groups to organize themselves in order to confront these obstacles. [...] The first AICs emerged during the colonial period as grassroots Christian movements. AIC leaders and prophets spread the gospel of Jesus Christ over wide areas of Africa, confronting spiritual, social and political evil in the community, and founding churches along the way. The majority of these leaders had little formal education and, more often than not, came from the ranks of the poorest and most vulnerable in society. Since political independence, AICs have continued to be founded, most of them describing themselves as Pentecostal", accessed December 18, 2020, http://www.oaic.org/?pa ge_id=51.

${ }^{4}$ Paul Gifford, "Christian Fundamentalism and Development," Review of African Political Economy 18, no. 52 (1991): 9-20.
} 
groups with their outwardly modern approach to the local situation and use of modern means of communication did not make any significant change as far as the modernisation of the society was concerned because they still operated within the same "enchanted" worldview. As long as that worldview prevails, there is no place for modernity.

In his book published in 2004, Gifford acknowledged some efforts of singular Neopentecostal groups' involvement in social projects. ${ }^{5}$ However, he indicated discrepancies between theory and praxis, e.g. the preachers urged church members to be hard working but at the same time demanded that they took time off work in order to participate in lengthy seminars and prayer sessions. ${ }^{6}$ In 2015 , he still reiterated his earlier opinion that the worldviews of "functional rationality" and those of "enchanted forces" could not be combined. He insisted that the two were alternative (not complementary) and incompatible. ${ }^{7}$ He rejected the notion of "multiple modernities", i.e. "that different people can take their place in the twenty-first century without becoming 'occidentalized'; they have their own way of being modern". He sternly subscribed to the notion of modernization as

that combination of changes - in the mode of production and government, in the social and institutional order, in the corpus of knowledge, and in attitudes and values - that makes it possible for a society to hold its own in the twenty-first century; that is, to compete on even terms in the generation of material and cultural wealth, to sustain its independence, and to promote and accommodate to further change. ${ }^{8}$

He would not have approved of the attitude in which one changes the perception of the reality when one cannot change the reality in order to accommodate it to the views one holds.

Reviewing Gifford's latest book Emma Wild-Wood regretted that, painting an excitingly broad picture of the religious dynamics in contemporary public life in Africa, Gifford had not bothered to check in what way the people he studied understood modernity.

\footnotetext{
${ }^{5}$ Paul Gifford, Ghana's New Christianity. Pentecostalism in a Globalising African Economy (London: Hurst \& Company, 2004), 140-160.

${ }^{6}$ Ibidem, 156-159.

7 Paul Gifford, Christianity, Development and Modernity in Africa (London: Hurst \& Company, 2015), 155-156.

${ }^{8}$ Ibidem, 152-155. He quoted David S. Landes, The Unbound Prometheus (Cambridge: Cambridge University Press, 1969), 6.
} 
Recent academic interest in Pentecostalism and Catholicism in Africa has generated work which examines smaller-scale responses of ordinary members to participation in local forms of religious practice. These fine-grained works of history and anthropology should be read alongside Gifford's macroscale analysis. ${ }^{9}$

A change of perception of reality has been taking place in recent years. Scholars (including some Western ones) tend to accept the fact that one should stop seeing the fears connected with witchcraft beliefs as aberrations. Instead, it should be taken for granted that these fears are real for the people who believe in spiritual causation. ${ }^{10}$ One should also stop seeing witchcraft as superstition from the past and a sign of backwardness. Instead, one should take into account the fact that the old witchcraft beliefs mutate and adapt to the current circumstances. They are not withering away in the modernized conditions but reappear in new forms, i.e. become modernized. ${ }^{11}$

Despite the insistence of scholars like Gifford on sticking to "classical" meanings of the concepts, the mental change has progressed. In a parallel way, the churches from the AIC group have been changing their approach to social engagement. In addition, the long-term social engagement of some of the old AICs - overlooked until recently - comes to be seen as genuine and entirely local (conducted with hardly any external help). Some contributors to the 2020 book on AICs as agents of development tend to perceive the AICs and their actions in a broadened perspective. They point out that because the concept of development and its implementation strategies had been defined by secular Western agents, they made no room for including the

\footnotetext{
${ }^{9}$ Emma Wild-Wood, [Review] "Gifford, Paul: Christianity, Development, and Modernity in Africa, London: C. Hurst and Company, 2015," Anthropos 111, no. 1 (2016): 257.

${ }^{10}$ Increasing number of researchers tends to admit that the witchcraft problems perceived by people are real and not imagined. See e.g. Kwabena Asamoah-Gyadu, "African Pentecostalism, Deliverance and Healing: Recent Developments and New Challenges," in Witchcraft, Demons and Deliverance. A Global Conversation on an Intercultural Challenge, eds. Claudia Währisch-Oblau, Henning Wrogemann (Zürich: LIT Verlag, 2015), 26. Birgit Meyer had very early on observed that for the early German missionaries working among the Ewe, the local gods and spirits had been real - not imaginary - agents of the devil. Birgit Meyer, "If you are a Devil, you are a Witch, and if you are a Witch, you are a Devil'. The Integration of 'Pagan' Ideas into the Conceptual Universe of Eve Christians in Southeastern Ghana," Journal of Religion in Africa 12 no. 2 (1992): 107-114.

${ }^{11}$ Peter Geschiere, The Modernity of Witchcraft: Politics and the Occult in Postcolonial Africa (Charlottesville, VA: University Press of Virginia, 1997) is a classical work on the topic. Stefen Ellis, and Gerrie ter Haar, World of Thought. Religious Thought and Political Power in Africa (Oxford: Oxford University Press, 2004).
} 
African understanding of development. ${ }^{12}$ The latter includes both the material-social and spiritual dimension. When one perceives the reality in such a perspective, then the title of the present article does not need to be enhanced with brackets. The current version of the concept of development, i.e. sustainable development ${ }^{13}$, can be attained (also) through undergoing spiritual deliverance.

\section{THE IMPACT OF PROSPERITY GOSPEL}

When I first turned my interest towards deliverance ministry as practiced within the West African Anglophone Neopentecostalism in the late 1990s, the main question concerned the socio-economic dimension of that ministry within the relatively new wave of Pentecostalism modified by the prosperity gospel. ${ }^{14}$ Could deliverance ministry bring about economic change and help people to alleviate the situation of poverty changing it into the promised economic success?

\footnotetext{
12 The editors refer to one of their earlier publication where they indicated that " $[t] h e$ development agenda and imagination, as framed in (inter-)governmental strategies such as the Agenda 2030 for Sustainable Development ... remains a secular one. Nowhere in the United Nations resolution on the Sustainable Development Goals (SDGs) is religion or are religious communities mentioned explicitly" (Öhlmann et al., eds., African Initiated Christianity and the Decolonisation of Development, 2).

${ }^{13}$ Sustainable development - "development that meets the needs of the present without compromising the ability of future generations to meet their own needs". United Nations General Assembly, Report of the world commission on environment and development: Our common future, United Nations General Assembly, Development and International Co-operation: Environment, Oslo 1987, 43. On the so-called Sustainable Development Goals set by the United Nations General Assembly in 2015 see accessed December 18, 2020, https://sdgs.un.org/goals.

${ }^{14}$ For a short description of prosperity gospel see below in the text. N. Gati and G. Os som-Batsa, capture the issue of its origin in a short and simple way: "Prosperity gospel originated in the US from the teaching of E.W. Kenyon, Oral Roberts and Kenneth and Gloria Copeland. In Africa, one of the earliest exponents was the Nigerian Archbishop Benson Idahosa, at whose school many of the contemporary Ghanaian leaders were formed." Nicoletta Gati, and George Ossom-Batsa, "Prosperity Gospel and the Poor: Intercultural Reading of Job 24:117," Interkulturelle Theologie. Zeitschrift für Missionswissenschaft 46, no. 1 (2020): 138, ftn 8. For an interdisciplinary approach to the analysis of prosperity gospel in Africa, see Andreas Heuser, ed., Pastures of Plenty: Tracing Religio-Scapes of Prosperity Gospel in Africa and Beyond (Frankfurt am Mein: Peter Lang, 2015). See also Emmanuel K. Anim, Who wants to be a Millionaire? An Analysis of Prosperity Teaching in the Charismatic Ministries (Churches) in Ghana and its Wider Impact (Berlin: LIT Verlag, 2020).
} 
The rise of the AICs of a more independent and Pentecostal form ${ }^{15}$ brought to the fore traits that resonated well with aspects of the Weberian "Protestant work ethic." From one side, there were scholars ${ }^{16}$ who pointed out new possible developmental effects of (at least) some new Neopentecostal groups - encouraging entrepreneurship and hard dedicated work, improved ways of living family life (abstention from alcohol, gambling and extramarital sex), active participation in elections, etc. These new improvements were not necessarily seen within a "developmental perspective" as that one was formulated with a view of broad economic and social changes defined and expected by the Western "pace-setters".

The gospel of prosperity twist brought the economic aspect of life definitely to the fore. It played the right tune in the ears of those who searched for a better life (=development). The promise and prospect of abundance motivated people to be entrepreneurial but also generous, although the latter tended to be perceived more in terms of investment ("I give my dues to God=the church/ pastor in order to acquire God's abundant material blessings"). ${ }^{17}$

Meanwhile, Gifford spearheaded the assumption that prosperity gospel used the cravings of people but led them in a false direction. He maintained that the prosperity gospel preached by the Neopentecostal preachers deceived people as to the real causes of socio-economic-political situation and could not bring its amelioration. Not "the spirits" were responsible for the current situation of material austerity but the structural oppressive systems and personal failures stood at the roots of it. The development was not to be attained through spiritual means but dedicated work and reasonable, transparent use of resources and production of goods for the common benefit. Contrary to the latter, the propagators of the prosperity gospel engaged in a redistribution of goods without producing anything new. It also seemed quite clear that that redistribution would privilege a small group of hyperactive individuals, moving them into the realm of the socalled "big men" (people with power, resources and prestige in society).

${ }^{15}$ Ghanaian scholar Kwabena Asamoah-Gyadu is one of the main proponents of seeing the old and new African Initiated Churches as belonging to one broad category.

${ }^{16}$ See e.g. Ruth Marshall, "Power in the Name of Jesus", Review of African Political Economy 18, no. 52 (1991): 25-7. The matter has been initially stronger argued by scholars researching the Pentecostal groups in Latin America, e.g. Bernice Martin, "New Mutations of the Protestant Ethic among Latin American Pentecostals", Religion 25, no. 2 (1995): 101-17.

${ }^{17}$ Emmanuel K. Anim remarked, "prosperity teaching was a response to socio-economic and political crisis [in the country - SG]". "An Evaluation of Pentecostal Churches as Agents of Sustainable Development in Africa", in African Initiated Christianity and the Decolonisation of Development, 143. 
In addition, Gifford underlined the disparity between the worldviews held by many Neopentecostal Christians in Africa and the development workers of non-African origin arriving with the development agenda defined along Western secular lines. He stressed that these views or beliefs were not of incidental character and even if some socio-economic and political aspects of life gave signs of change for the better, that change was not accompanied by more fundamental change of mentality and its accompanying world view, therefore was accidental. ${ }^{18}$

The saturation of the Neopentecostal movement with the gospel of prosperity spilled over to the other segments of Christianity (and beyond) and brought about unexpected results (see below). ${ }^{19}$ The teaching that not only justified but encouraged striving for economic prosperity fell in Africa on fertile ground. Prosperity gospel, maintaining that true (new-born) Christians were meant to live the life of success and abundance (earned and secured for them by Jesus), has been preached, implemented (although with rather limited success) in life but also criticised by many during the last thirty years, and not only in Africa. The critics of the prosperity gospel from various strands of Christianity, while acknowledging advantages it brought, pointed out its deficiencies but particularly its worrisome theological consequences. ${ }^{20}$ The teaching of prosperity gospel retrieves the retributive theology of the Old Testament. Believers treat God in an instrumental way expecting immediate blessings for their faith. Seeing suffering and pain as a result of lack of faith (i.e. a failure) gives no space and no consideration to innocent/unjust suffering. The demand to take the word of God literally (without any contextualisation) is often extended to the word of the pastor or prophet. His/her utterances cannot be contested or discussed. ${ }^{21}$

\footnotetext{
${ }^{18}$ He reiterated his earlier views in the conclusions of the 2015 book.

19 The mainline churches had to make their own adaptations of deliverance sessions in order not to lose members to the Neopentecostal groups.

${ }^{20}$ The most obvious apparent advantages: encouraging entrepreneurship; creating employment in schools, banks, hospitals; encouraging the members to be generous and to hold a holistic approach to life. The deficiencies: the promise of prosperity is not realised; prosperity gospel takes away personal responsibility; prosperity gospel ignores social injustice. Lovemore Togarasei, "The Pentecostal Gospel of Prosperity in African Contexts of Poverty," Exchange 40, no. 4 (2011): 342, quoted in Gati, and Ossom-Batsa, "Prosperity Gospel", 142-3. See also Statement on the prosperity gospel issued by Lausanne Theology Working Group accessed December 18, 2020, https://www.lau sanne.org/content/a-statement-on-the-prosperity-gospel.

${ }^{21}$ Gati, and Ossom-Batsa, "Prosperity Gospel", 142-143.
} 


\section{REMEDY THROUGH DELIVERANCE}

Hindrances in accessing the riches that supposedly were due to every newborn Christian but somehow could not materialise in the lives of many of them, were to be overcome by deliverance ministry. Abamfo O. Atiemo pointed out to two levels of understanding deliverance. It can be addressed in terms of freeing people form the bondage of Satan in its broad sense or in terms of removing "sickness, setbacks, torments and other physical infirmities". The deliverance ministry propagated or inspired by the new Pentecostal groups has relied more on the second narrower understanding and is perceived as a kind of necessary step towards attaining salvation. In explaining it, they use the image of Lazarus raised from the dead by Jesus but still bound by his grave-clothes. ${ }^{22}$

Deliverance ministry has a long history within the Christian context ${ }^{23}$ but in the 1980s and 1990s, it started to be employed within the Neopentecostal circles as a "corrective tool" within the prosperity gospel teaching. According to the prosperity gospel teaching, as a Christian, one is supposed to live a plentiful life, also materially. The frustration coming from the fact that despite "sawing" - as the prosperity gospel fostered - the expected riches failed to appear in life of many, led to adopting and adapting the practice of deliverance (from the oppression of evil) as a corrective tool in the process of attaining the fullness of life (material and spiritual prosperity). When one could not attain riches, it was because demons oppressed the Christian and blocked his/her way to the promised life of plenty. The demons had to be castigated during deliverance sessions. Deliverance, i.e. removing obstacles on the way to attaining the fullness of life already on earth, was naturally seen in terms of being freed from oppression by evil and increasingly perceived by people as fighting against witchcraft.

At the end of the $20^{\text {th }}$ century, various deliverance ministries started operating within and outside of recognised Christian movements. The teaching and accompanied practice developed in an uncontrolled way, often in response to the current needs and demands on the part of the oppressed. The components coming from the Western preachers (particularly Derek Prince

\footnotetext{
22 Abamfo Ofori Atiemo, "Deliverance in the Charismatic Churches in Ghana," Trinity Journal of Church and Theology 4, no. 95 (1994): 40-41.

${ }^{23}$ Stephen Hunt, "Deliverance: The Evolution of a Doctrine," Themelios 21, no. 1 (1995): 10-13; Stephen Hunt, "Managing the Demonic Some Aspects of the Neo-Penetcostal Deliverance Ministry," Journal of Contemporary Religion 13, no. 2 (1998): 215-230.
} 
and Rebeca Brown) cannot be overlooked but the African preachers did not feel constrained by the Western input. They rather creatively adapted it to the locally existing worldview. Gifford added that although the beliefs underpinning the deliverance thinking were also challenged from within some of the Pentecostal-charismatic churches, the demand on the side of the people to carry out deliverance sessions was so strong that also many critics had to give in and comply with the demand in order not to lose members. ${ }^{24}$

\section{THE ANTI-WITCHCRAFT TWIST}

Because striving to be freed from the oppression by evil corresponds with the ages-long fight against the forces of evil that have been called "witchcraft" in the European languages, the new (Christian) practice somehow took over the earlier anti-witchcraft movements. ${ }^{25}$ It was clear to the people concerned that the hindrances preventing one from obtaining the life of abundance were not (only) of secular character, i.e. there were often spiritual causes that had to be overcome. For the Africans, all matters of life have their spiritual side that needs to be attended to regardless of what is happening on the physical-visible level.

Since the old fears of witchcraft have never been actually extinguished among many people outside Europe, the new practice (deliverance) has increasingly attained the old well-known characteristics of anti-witchcraft fight. In a more Christianized environment, it was gaining popularity because it seemed to give a "Christian" answer to the old problem (witchcraft). From the point of view of the Africans, the mainline mission churches were unable to address the problem properly and effectively.

With the flow of time, attending to the matters on the spiritual level took precedence up to the point that deliverance became a new anti-witchcraft tool. In the 1990s and 2000s, spiritual combat against witchcraft - in the form of deliverance - proliferated and captivated the attention not only of many Christians but also of those who researched Christian communities. That time the impact of the "spiritual concern" sent shockwaves not only across the Christian churches locally but also across the globe. ${ }^{26}$

\footnotetext{
${ }^{24}$ Gifford, Ghana's New Christianity, 88.

${ }^{25}$ Opoku Onyinah, "Deliverance as a way of confronting witchcraft in modern Africa: Ghana as a case history," Asian Journal of Pentecostal Studies 5, no. 1 (2002): 107-134.

${ }^{26}$ The effects have been traceable beyond the Pentecostal-charismatic circles, e.g. in the
} 
The subsequently growing concern with "combating witchcraft" seemed to substantiate claims that although the Neopentecostal Christianity and the tools it employed might have seemed "modern", everything was ultimately recast in the well-known in Africa pattern of combating witchcraft. ${ }^{27}$ It was nothing particularly new in the history of religious movements in Africa.

The witchcraft beliefs cannot be simply abolished and they have not vanished despite the educational efforts. Many well-educated people share the old witchcraft beliefs with their uneducated compatriots. The problem acquires a new level of complication, when people want to (or have to) collaborate in global networks. That poses problems for example, for the Christian churches. Can Christians belonging to the same church but holding different theologies cooperate?

Claudia Währisch-Oblau and Henning Wrogemann gathered the material depicting the problem for the United Evangelical Mission (UEM) that groups churches from Germany, Africa and Asia. ${ }^{28}$ In her summary of the work of two think tanks that had tackled the problems of handling witchcraft accusations and deliverance ministry Währisch-Oblau wrote:

It was felt that arguments about whether demons are 'real' in an ontological sense would not bring any results, while in contrast, the very real consequences of demon beliefs (witch hunts with their economic, social and political fallouts, syncretistic practices to ward off curses, psychological effects like paralyzing fear) were obvious to all. Consequently, both think tanks decided to stick to a phenomenological and constructivist approach, looking at popular beliefs and fears and trying to understand them on their own terms as one possible and viable interpretation of certain phenomena which nevertheless also might have other explanations - but each of these interpretations are constructions and not 'objective'. ${ }^{29}$

Roman Catholic Church in Poland. In 2015, the Bishops' Conference issued a formal statement forbidding certain practices, e.g. so-called gateway confessions and healing an "intergenerational guilt" (theories and practices rather foreign to the Roman Catholic theology). The ban incited a laud protest in the social media. See also Andrzej Kobyliński, "Egzorcyzmy nad Polską i pentekostalizacja," Do Rzeczy July 7, 2017, accessed December 18, 2020, https://dorzecz y.pl/kraj/34674/Egzorcyzm and an interview with Andrzej Kobyliński about what he calls "a brutal ideological war" within the Roman Catholic Church in Poland, accessed December 18, 2020, https://trojmiasto.onet.pl/wojna-religijna-w-polskim-kosciele-rozmowa-z-ks-prof-an drzejem-kobylinskim/fk869d0.

${ }^{27}$ See e.g. an overview of the situation in Gerrie ter Haar, ed., Imagining Evil. Witchcraft Beliefs and Accusations in Contemporary Africa (Trenton, NJ: Africa World Press, Inc., 2007).

${ }^{28}$ Claudia Währisch-Oblau, and Henning Wrogemann, eds., Witchcraft, Demons and Deliverance. Witchcraft, Demons and Deliverance. A Global Conversation on an Intercultural Challenge (Zürich: LIT Verlag, 2015).

${ }^{29}$ Claudia Währisch-Oblau, "Towards a Protestant Ministry of Deliverance," in Witchcraft, Demons and Deliverance, 194-195. 
Avoiding the unresolvable ontological debates (whether spirits "really" exist or not), the participants were able to develop pastoral responses to problems that bothered people in their everyday life. Währisch-Oblau asserts that it comes to taking a strange position - "you don't have to believe in demons to drive them out" - but at the same time points out that both teams drew up "consensus documents outlining a theological basis and pastoral guidelines for a Protestant deliverance ministry." ${ }^{30}$ It seems that some progress was made in the problem of handling witchcraft beliefs, although the documents and decisions were not conclusive. The matter still requires further consideration.

\section{SOCIAL ENGAGEMENT FOR DEVELOPMENT}

With the Neopentecostal Christianity becoming more than an ephemeral movement (although laud, colourful and vibrant) on the outskirts of the Christian world, there were first indications that the Neopentecostals had been after all - active collectively on the social level, i.e. for the benefit of community and not only for individual profit. They were engaged in social projects - schools and universities, hospitals and health care centres, micro credits, etc. They have initiated these endeavours often without any external financial help. Donald E. Miller and Tetsuano Yamamori drew a new and intriguing picture of social involvement of various Pentecostal groups around the world before 2007. In that way, they countered the commonly held perception about the other-worldly-only focus of these groups. ${ }^{31}$ Other, already quite old but mostly overlooked by researchers until recently, examples of social engagement of Pentecostals are brought to the public attention. ${ }^{32}$ With an eye open on the big urban churches, Asamoah-Gyadu asserts, "Contemporary Pentecostals, which in the past propounded a simplistic gospel of prosperity now combine that with significant emphasis on social and econo-

\footnotetext{
${ }^{30}$ Ibidem. More updated information: accessed December 18, 2020, https://www.vemission. org/themen/evangelisation/missionstheologie.html.

31 They called these groups "Progressive Pentecostals". Donald E. Miller, and Totsunao Yamamori, Global Pentecostalism: The New Face of Christian Social Engagement (Berkeley: University of California Press, 2007).

32 E.g. Opoku Onyinah, "Distinguished Church Leader Essay. The Church of Pentecost and its Role in the Ghanaian Society," in African Initiated Christianity and the Decolonisation of Development, 188-192.
} 
mic development". ${ }^{33}$ However, Andreas Heuser warns, that "[g]eneralising statements on Prosperity Gospel churches as modern agents for socioeconomic transformation need to be tested by comparative case-study approaches in different social contexts". He further indicated that the small rural AICs have been rather more reactive than pro-active and most of their activities are placed more within the scope of a struggle for survival than making a structural impact on the society at large. ${ }^{34}$

So far, measurable proof of African Pentecostal agency to improve social life is small. Some initiatives, however, direct towards strategic implementation of entrepreneurial praxis. They are characterised by long-term networking beyond the range of the same church or church family. Such interaction is basically generated between African Progressive Pentecostals and American churches of the evangelical left, that is churches with a stronger socio-political profile. ${ }^{35}$

\section{6. "DECOLONISATION OF DEVELOPMENT"}

With the new approach branded as "decolonisation of development", i.e. defining the terms in a way that includes the views of addressees-collaborators, one can see that both perspectives on the meaning of development, i.e. the "secular-Western" and the "African" - draw near to each other. In his contribution to the 2020 book on the AICs and development, Kwabena Asamoah-Gyadu argues that

Development has to do with visible, enduring, and measurable qualitative upward mobility in human life and society. Its associated terms and expressions include expansion, growth, progress, success and prosperity. Religion, on the other hand, is about the relationship between two realms of existence - the divine and the human - and all that goes into making life empowering, better, and worth living. When people and societies develop, the desire to live increases because life becomes meaningful. ${ }^{36}$

${ }^{33}$ Kwabena Asamoah-Gyadu, "Spirit and Empowerment. The African Initiated Church movement and development," in African Initiated Christianity and the Decolonisation of Development, 43.

34 Andreas Heuser, "Charting African Prosperity Gospel economies," HTS Teologiese Studies/Theological Studies 72, no. 2 (2016): 7.

35 Ibidem, 7-8.

${ }^{36}$ Asamoah-Gyadu, Spirit and Empowerment, 34. 
Asamoah-Gyadu calls the new perspective on the beliefs and practices of the AICs "human flourishing", emphasising that "spiritual and physical empowerment for upward mobility lies at the heart of discourses on prosperity". Old AICs (known in Ghana as Spiritual Churches) "advertised their services as places where people could achieve development in all their lives". ${ }^{37} \mathrm{He}$ maintains that the Neopentecostal groups continue that old discourse. In that way, from the African perspective, development and religion are not exclusive or opposite but complementary. Development for the Africans has always included a spiritual dimension and there is nothing surprising that one tries to achieve development (i.e. be modern) making use of such practices as deliverance ministry, i.e. being freed from disruptive spiritual forces. Material development has always had spiritual underpinning. That aspect has been clearly highlighted by various contributors to the 2020 book. It remains to be seen whether the Western proponents of development accept, adopt and adapt that perspective, and whether their partners from the AICs will be convincingly successful in the implementation of newly perceived and formulated sustainable development projects.

\section{BIBLIOGRAPHY}

Anim, Emmanuel K. Who wants to be a Millionaire? An Analysis of Prosperity Teaching in the Charismatic Ministries (Churches) in Ghana and its Wider Impact. Berlin: LIT Verlag, 2020.

Anim, Emmanuel K. "An Evaluation of Pentecostal Churches as Agents of Sustainable Development in Africa." In African Initiated Christianity and the Decolonisation of Development, eds. Philipp Öhlmann, Wilhelm Gräb, and Marie-Luise Frost. 195-211. London-New York: Routledge, 2020.

Asamoah-Gyadu, Kwabena. "African Pentecostalism, Deliverance and Healing: Recent Developments and New Challenges." In Witchcraft, Demons and Deliverance. A Global Conversation on an Intercultural Challenge, eds. Claudia Währisch-Oblau, and Henning Wrogemann. 17-39. Zürich: LIT Verlag, 2015.

Asamoah-Gyadu, Kwabena. "Spirit and Empowerment. The African Initiated Church movement and development." In African Initiated Christianity and the Decolonisation of Development, eds. Philipp Öhlmann, Wilhelm Gräb, and Marie-Luise Frost. 33-50. London-New York: Routledge, 2020.

\footnotetext{
${ }^{37}$ Ibidem, 34, 37. However, he indicates clearly that in the erstwhile independent and
} Pentecostal churches wealth was frowned upon (p. 38). 
Atiemo, Abamfo Ofori. "Deliverance in the Charismatic Churches in Ghana." Trinity Journal of Church and Theology 4, no. 95 (1994): 39-49.

Ellis, Stefen, and Gerrie ter Haar. World of Thought. Religious Thought and Political Power in Africa. Oxford: OUP, 2004.

Gati, Nicoletta, and George Ossom-Batsa. "Prosperity Gospel and the Poor: Intercultural Reading of Job 24:1-17." Interkulturelle Theologie. Zeitschrift für Missionswissenschaft 46, no. 1 (2020): 135-157.

Geschiere, Peter. The Modernity of Witchcraft: Politics and the Occult in Postcolonial Africa. Charlottesville, VA: University Press of Virginia, 1997.

Gichimu, John Njeru. "History and Profile of OAIC." In Anthology of African Christianity, eds. Izabel Apawo Phiri et al. 810-818. Oxford: Regnum Books International, 2016.

Gifford, Paul. "Christian Fundamentalism and Development." Review of African Political Economy 18, no. 52 (1991): 9-20.

Gifford, Paul. Ghana's New Christianity. Pentecostalism in a Globalising African Economy. London: Hurst \& Company, 2004.

Gifford, Paul. Christianity, Development and Modernity in Africa. London: Hurst \& Company, 2015.

Heuser, Andreas, ed. "Pastures of Plenty:" Tracing Religio-Scapes of Prosperity Gospel in Africa and Beyond. Frankfurt am Main: Peter Lang, 2015.

Heuser, Andreas. "Charting African Prosperity Gospel economies." HTS Teologiese Studies / Theological Studies 72, no. 1 (2016): 1-9.

Hunt, Stephen. "Deliverance: The Evolution of a Doctrine." Themelios 21, no. 1 (1995): 10-13.

Hunt, Stephen. "Managing the Demonic Some Aspects of the Neo-Penetcostal Deliverance Ministry." Journal of Contemporary Religion 13, no. 2 (1998): 215-230.

Landes, David S. The Unbound Prometheus. Cambridge: Cambridge University Press, 1969.

Marshall, Ruth. "Power in the Name of Jesus." Review of African Political Economy 18, no. 52 (1991): 21-37.

Martin, Bernice. "New Mutations of the Protestant Ethic among Latin American Pentecostals." Religion 25, no. 2 (1995): 101-117.

Meyer, Birgit. "'If you are a Devil, you are a Witch, and if you are a Witch, you are a Devil'. The Integration of 'Pagan' Ideas into the Conceptual Universe of Eve Christians in Southeastern Ghana." Journal of Religion in Africa 12, no. 2 (1992): 98-132.

Miller, Donald E., and Tetsunao Yamamori. Global Pentecostalism: The New Face of Christian Social Engagement. Berkeley: University of California Press, 2007.

Öhlmann, Philipp, Wilhelm Gräb, and Marie-Luise Frost, eds. African Initiated Christianity and the Decolonisation of Development. Sustainable Development in Pentecostal and Independent Churches. Abingdon: Routledge, 2020.

Onyinah Opoku. "Deliverance as a way of confronting witchcraft in modern Africa: Ghana as a case history." Asian Journal of Pentecostal Studies 5, no. 1 (2002): 107-134.

Onyinah Opoku. "Distunguished Leader Essay. The Church of Pentecost and its Role in the Ghanaian Society." In African Initiated Christianity and the Decolonisation of Development, eds. Philipp Öhlmann, Wilhelm Gräb, and Marie-Luise Frost. 183-194. London-New York: Routledge, 2020.

Ter Haar, Gerrie, ed. Imagining Evil. Witchcraft Beliefs and Accusations in Contemporary Africa. Trenton, NJ: Africa World Press, Inc., 2007.

Togarasei, Lovemore. "The Pentecostal Gospel of Prosperity in African Contexts of Poverty. An Appraisal." Exchange 40, no. 4 (2011): 336-350. 
United Nations General Assembly. Report of the world commission on environment and development: Our common future. United Nations General Assembly, Development and International Co-operation: Environment, Oslo 1987.

Währisch-Oblau, Claudia. "Towards a Protestant Ministry of Deliverance." In Witchcraft, Demons and Deliverance. A Global Conversation on an Intercultural Challenge, eds. Claudia Währisch-Oblau, and Henning Wrogemann. 187-208. Zürich: LIT Verlag, 2015.

Währisch-Oblau, Claudia, and Henning Wrogemann, eds. Witchcraft, Demons and Deliverance. A Global Conversation on an Intercultural Challenge. Zürich: LIT Verlag, 2015.

Wild-Wood, Emma. [Review] "Gifford, Paul: Christianity, Development, and Modernity in Africa. London: C. Hurst and Company, 2015.” Anthropos 111, no. 1 (2016): 257.

http://www.oaic.org/?page_id=51

https://sdgs.un.org/goals

Kobyliński, Andrzej. "Egzorcyzmy nad Polską i pentekostalizacja." Do Rzeczy. July 7, 2017. Accessed December 18, 2020. https://dorzeczy.pl/kraj/34674/Egzorcyzm

Kobyliński, Andrzej. [Interview] Accessed December 18, 2020. https://trojmiasto.onet.pl/ wojnareligijna-w-polskim-kosciele-rozmowa-z-ks-prof-andrzejem-kobylins kim/ fk869d0

Lausanne Theology Working Group. Statement on the prosperity gospel.

https://www.lausanne.org/content/a-statement-on-the-prosperity-gospel

https://www.vemission.org/themen/evangelisation/missionstheologie.html

\title{
(ZRÓWNOWAŻONY) ROZWÓJ POPRZEZ POSŁUGE WYBAWIENIA W AFRYCE ZACHODNIEJ?
}

\author{
S t r e s z c z e n i e
}

Można by się zastanawiać, co obie wymienione w tytule zagadnienia mają ze sobą wspólnego, ponieważ należą do dwóch zgoła odmiennych percepcji świata. W zakończeniu swojej ostatniej książki (2015) Paul Gifford nadal upierał się, że rozwój - pojmowany w duchu zachodniego sekularyzmu - jest prawie niemożliwy tam, gdzie ludzie nadal funkcjonują w obrębie „zaczarowanego” światopoglądu. Wydaje się jednak, że ta „niemożność” może faktycznie stać się możnością, choć dzięki zastosowaniu dość zaskakującego zabiegu intelektualnego zwanego ,dekolonizacją rozwoju”.

Słowa kluczowe: African-Initiated Churches; neopentekostalizm; zrównoważony rozwój; posługa wybawienia. 